\title{
Long-term Effect of Temperature and Triadimefon on Proliferation of Uncinula necator: Implications for Fungicide Resistance and Disease Risk Assessment
}

\author{
H. L. Ypema and W. D. Gubler, Department of Plant Pathology, University of California, Davis 95616
}

\begin{abstract}
Ypema, H. L., and Gubler, W. D. 1997. Long-term effect of temperature and triadimefon on proliferation of Uncinula necator: Implications for fungicide resistance and disease risk assessment. Plant Dis. 81:1187-1192.

Triadimefon has been used in California to control Uncinula necator, causal agent of grape powdery mildew, since 1982. Instances of unsatisfactory control have occurred mainly in the cooler coastal areas of California. The effect of temperature and application of triadimefon was investigated over a 53-day-period on two $U$. necator isolates, sensitive and resistant to triadimefon. At $15^{\circ} \mathrm{C}, 25^{\circ} \mathrm{C}$, or temperatures fluctuating between 15 and $25^{\circ} \mathrm{C}$, in absence of triadimefon, the isolates continued to produce high numbers of conidia for the entire duration of the experiment. Sporulation declined at daily maximum temperatures of $32^{\circ} \mathrm{C}$ for $6 \mathrm{~h}, 36^{\circ} \mathrm{C}$ for $3 \mathrm{~h}$, and $40^{\circ} \mathrm{C}$ for $1 \mathrm{~h}$, but was detectable when the experiment was terminated. At these temperature regimes, sporulation of the triadimefon-treated sensitive isolate ceased after 23 days. When treated with triadimefon, sporulation of the resistant isolate was comparable to that of the watertreated control. At daily maximum temperatures of $32^{\circ} \mathrm{C}$ for $11 \mathrm{~h}, 36^{\circ} \mathrm{C}$ for $6 \mathrm{~h}$, and $40^{\circ} \mathrm{C}$ for 3 $\mathrm{h}$, sporulation of both isolates generally ceased after 23 days, regardless of triadimefon application. Triadimefon resistance is most likely to manifest itself under high disease pressure, which is in part a function of temperature. The duration of daily maximum temperatures may be a valuable addition to disease risk assessment models.
\end{abstract}

Uncinula necator (Schwein.) Burrill, causal agent of powdery mildew, is of economic importance in all grape-producing areas in California. Disease pressure generally is most severe in the coastal regions of California. It is less severe in most areas of the Sacramento and San Joaquin Valleys $(2,4)$. Differences in summer temperature may account for most of the regional differences in disease pressure $(2,4)$. The optimum temperature range for growth and development of $U$. necator is between 21 and $30^{\circ} \mathrm{C}(2,8)$. These temperatures occur frequently for long durations each day during the growing season in the coastal regions of California. Temperatures higher than $33.5^{\circ} \mathrm{C}$ inhibit conidial germination, whereas infection is impaired at temperatures higher than $31.5^{\circ} \mathrm{C}$ (2). U. necator colonies do not survive prolonged exposure to temperatures of $37^{\circ} \mathrm{C}$ and higher (2). These conditions frequently occur in the Sacramento and San Joaquin Valleys.

Corresponding author: H. L. Ypema

Current address: BASF Corporation, P.O. Box 13528, Research Triangle Park, North Carolina 27709.

E-mail: Hendrik.Ypema@raleigh.basf-corp.com

Funding for this research was provided by Dow Elanco, Indianapolis, IN, and the Andre Tchelistcheff Scholarship Fund.

Accepted for publication 11 July 1997.

Publication no. D-1997-0820-02R

(C) 1997 The American Phytopathological Society
The demethylation-inhibiting (DMI) fungicide triadimefon (Bayleton, Bayer Corp., Agricultural Chemical Division, Kansas City, MO) was registered for powdery mildew control in California in 1982. During the 1985 and 1986 growing seasons, reduced efficacy of triadimefon was observed in some California vineyards (7). In the coastal regions, triadimefon alone has not provided satisfactory control since 1986 (7). Control in the Central and San Joaquin Valleys has been generally adequate in years subsequent to 1986 (7). Decreased sensitivity to triadimefon was confirmed and was more prominent in $U$. necator subcultures collected from the central coast region than in those from other California regions, particularly the San Joaquin Valley (4). Temperature is the principal factor in determining the extent of asexual reproduction in $U$. necator $(1,2)$, but the effect of fluctuating temperatures on proliferation of $U$. necator and on triadimefon efficacy has not been studied. The first objective of this research was to determine the influence of fluctuating temperatures on conidial germination of two $U$. necator isolates, sensitive and resistant to triadimefon. The second objective was to monitor proliferation of the same $U$. necator isolates for an extended time period at the same daily temperature regimes, under presence and absence of triadimefon.

\section{MATERIALS AND METHODS}

Fungal isolates. The triadimefon-sensitive $U$. necator isolate originated from a vineyard that was never treated with DMI fungicides $(4,9)$. The triadimefon-resistant isolate originated from a Central Coast vineyard (4) in which powdery mildew control by triadimefon was unsatisfactory (4). Isolates were cultured twice from single conidia (3), and maintained on mildewfree seedlings of Vitis vinifera L. (cv. Carignane) in isolation tubes (9). $\mathrm{EC}_{50}$ values of triadimefon were determined for the triadimefon-sensitive isolate $(2.5 \pm$ $0.55 \mathrm{mg} /$ liter) and the triadimefon-resistant isolate $(48.7 \pm 3.77 \mathrm{mg} / \mathrm{liter})$ by means of a leaf disc bioassay (9). The sensitive and resistant isolate were completely inhibited by $30 \mathrm{mg} / \mathrm{liter}$ and $200 \mathrm{mg} / \mathrm{liter}$ triadimefon, respectively.

Effect of temperature on conidial germination. Leaf discs (10-mm-diameter) were cut from 6-day-old leaves of mildew free grapevine cuttings cv. Carignane. Leaf discs were placed in petri plates lined with two layers of moistened paper towel and Miracloth (Calbiochem, La Jolla, CA), and inoculated separately with conidia of the sensitive and resistant isolate (9). Inoculum densities were determined with a hemacytometer and ranged from 600 to 700 conidia/ $\mathrm{cm}^{2}$. After inoculation, leaf discs were incubated at one of the following temperature regimes: $15^{\circ} \mathrm{C}$ for $24 \mathrm{~h}, 22^{\circ} \mathrm{C}$ for $24 \mathrm{~h}, 25^{\circ} \mathrm{C}$ for $24 \mathrm{~h}, 32^{\circ} \mathrm{C}$ for $24 \mathrm{~h}, 32^{\circ} \mathrm{C}$ for $6 \mathrm{~h}$ followed by $22^{\circ} \mathrm{C}$ for 18 $\mathrm{h}, 32^{\circ} \mathrm{C}$ for $12 \mathrm{~h}$ followed by $22^{\circ} \mathrm{C}$ for $12 \mathrm{~h}$, $36^{\circ} \mathrm{C}$ for $3 \mathrm{~h}$ followed by $22^{\circ} \mathrm{C}$ for $21 \mathrm{~h}$, $36^{\circ} \mathrm{C}$ for $6 \mathrm{~h}$ followed by $22^{\circ} \mathrm{C}$ for $18 \mathrm{~h}$, $40^{\circ} \mathrm{C}$ for $1 \mathrm{~h}$ followed by $22^{\circ} \mathrm{C}$ for $23 \mathrm{~h}$, and $40^{\circ} \mathrm{C}$ for $3 \mathrm{~h}$ followed by $22^{\circ} \mathrm{C}$ for $21 \mathrm{~h}$. Temperatures in the incubators were monitored with a mercury thermometer positioned near the petri dishes. After $24 \mathrm{~h}$, mounts were made from the inoculated upper leaf disc surfaces using transparent plastic tape (Scotch, 3M Packaging Systems, St. Paul, MN). Tape segments were mounted onto microscope slides and stained with a solution of $0.5 \mathrm{~g} /$ liter basic fuchsin in $85 \%$ lactic acid. Conidia were examined microscopically for germination at $100 \times$. Conidia were considered germinated when germ tube length had exceeded the width of the conidium. The experiment was performed twice, each with three replications of 100 conidia. An exploratory analysis of the entire data set was performed with analysis of variance (ANOVA) procedure in SAS (SAS Institute Inc., Cary, NC). A Dunnett's $t$ test $(P=0.05)$ was performed on the data of each isolate and experiment to determine whether percentages of germination were significantly different from those at $22^{\circ} \mathrm{C}$. 
This temperature was the minimum temperature used in most of the fluctuating temperature regimes described in the following section.

Effect of temperature and triadimefon on sporulation. The respective isolates were inoculated separately onto 4- to 6week-old grape seedlings, cv. Carignane, which had been placed in 30-cm-high, 20liter water containers (Alhambra Water Company, Pasadena, CA), from which the tops had been removed. Eleven seedlings were placed in each container prior to inoculation. Plants in each container were inoculated by dusting conidia from mildew colonies on three previously infected grape seedlings. After inoculation, the water containers were sealed with two layers of paper towel and secured with tape and rubber bands. The containers were placed in a greenhouse at $25^{\circ} \mathrm{C}$ for 2 weeks to allow for establishment of the $U$. necator isolates on the grape seedlings. Thereafter, the containers were placed in growth chambers (Conviron, model PGR 15, Controlled Environments Inc., Winnipeg, Manitoba, Canada) at one of the following daily temperature regimes : $15^{\circ} \mathrm{C}$ for $24 \mathrm{~h}$, $22^{\circ} \mathrm{C}$ for $24 \mathrm{~h}, 25^{\circ} \mathrm{C}$ for $24 \mathrm{~h}, 32^{\circ} \mathrm{C}$ for 24 h, $32^{\circ} \mathrm{C}$ for $6 \mathrm{~h}$ and $22^{\circ} \mathrm{C}$ for $16 \mathrm{~h}, 32^{\circ} \mathrm{C}$ for $11 \mathrm{~h}$ and $22^{\circ} \mathrm{C}$ for $11 \mathrm{~h}, 36^{\circ} \mathrm{C}$ for $3 \mathrm{~h}$ and $22^{\circ} \mathrm{C}$ for $19 \mathrm{~h}, 36^{\circ} \mathrm{C}$ for $6 \mathrm{~h}$ and $22^{\circ} \mathrm{C}$ for $16 \mathrm{~h}, 40^{\circ} \mathrm{C}$ for $1 \mathrm{~h}$ and $22^{\circ} \mathrm{C}$ for $21 \mathrm{~h}$, and $40^{\circ} \mathrm{C}$ for $3 \mathrm{~h}$ and $22^{\circ} \mathrm{C}$ for $19 \mathrm{~h}$. The period of temperature change between maximum and minimum was $1 \mathrm{~h}$. The temperature was measured and controlled to an accuracy of $0.5^{\circ} \mathrm{C}$ by a sensor in the growth chamber. The temperature inside the sealed containers was similar to the ambient growth chamber temperature (Solomat Thermohygrometer, model \#455; Solomat, Norwalk, CT 06850). Due to the presence of free moisture on the container bottoms, the relative humidity $(\mathrm{RH})$ in the containers ranged from 90 to $95 \%$ at all temperature regimes (Solomat Thermo- hygrometer). The light intensity inside the containers was $32.7 \mu \mathrm{mol} \cdot \mathrm{s} \cdot \mathrm{m}^{2}$ (LI-COR Quantum/Radiometer Photometer, Model LI-189, LI-COR, Lincoln, NE). To prevent contamination by $U$. necator, containers were placed in a separate rooms when subjected to treatments which required opening of the paper towel seal, such as the initial inoculation, watering, sample collection, or fungicide application.

Conidial counts were taken from the seedlings in each container at six times throughout the incubation period. At each sampling time, 10 10-mm-diameter leaf discs were cut at random out of the leaves of the infected grape seedlings in one container by means of a sharp cork borer. The cork borer was disinfected with $95 \%$ ethanol and allowed to dry between collections of leaf discs from each container. Each collection of leaf discs was placed in a 50 $\mathrm{ml}$ plastic centrifuge tube, containing 10 $\mathrm{ml}$ of an aqueous solution of $0.15 \%$ sodium dodecyl sulfate (SDS) and $1.5 \% \mathrm{NaCl}$. Conidia were counted by modifying a method previously described (1). Leaf discs were hand-agitated for $10 \mathrm{sec}$ and approximately $0.2 \mathrm{ml}$ of the solution was placed on a hemacytometer with $1 \mathrm{~mm}^{2}$ squares. For each sample, this resulted in a detection limit of approximately 100 con$\mathrm{idia} / \mathrm{cm}^{2}$ of leaf surface area. The first sampling was performed when the inoculated plants were subjected to the abovementioned temperature regimes. The second sampling was performed 9 to 12 days later. The third sampling was performed 19 to 23 days after the first sampling. The fourth, fifth, and sixth samplings were performed after 30 to 34,41 to 43 , and 51 to 53 days, respectively.

After the first collection of leaf discs, the treated plants were sprayed to run-off with a solution of $150 \mathrm{mg} /$ liter triadimefon (Bayleton $50 \mathrm{DF}$ ) in distilled water in a hand-pump sprayer. Control plants were sprayed to run-off with distilled water. This procedure was repeated after the third leaf disc collection and after the fifth leaf disc collection. The experiment was performed with three replications, with one container representing one replication. The experiment was repeated once. A value of 0.5 was added to the counted numbers of conidia, and the resulting values were transformed to natural logarithms to stabilize variances. The data were analyzed using the general linear methods procedure in SAS. An exploratory analysis was performed with experiment, isolate, temperature regime, and triadimefon treatment as main effects. The times at which leaf discs were collected were incorporated into the model as repeated measurements. Subsequently, data were analyzed separately for each experiment, temperature regime, and isolate. In these separate analyses, the main effect was the triadimefon treatment. The leaf disc collection times, hereafter referred to as sampling times, were again incorporated as repeated measurements. The significance of the triadimefon treatment effect was determined by the magnitude of the $F$ value for the interaction between treatment and collection time $(P=$ $0.05)$.

\section{RESULTS}

Effect of temperature on conidial germination. The exploratory ANOVA showed a significant effect of temperature regime, isolate, and experiment $(P<$ $0.01)$. Interactions between experiment and temperature, and isolate and experiment were also significant $(P<$ 0.01 ), and justified the separate analyses for each experiment and isolate (Table 1). For both isolates, the germination rate was consistently highest at $25^{\circ} \mathrm{C}$. Germination at $22^{\circ} \mathrm{C}$ did not differ significantly from germination at $25^{\circ} \mathrm{C}$ in either experiment or isolate. For both isolates, germination at all other temperature

Table 1. Conidial germination percentage ${ }^{\mathrm{v}}$ of two Uncinula necator isolates at various temperature regimes

\begin{tabular}{|c|c|c|c|c|}
\hline \multirow[b]{2}{*}{ Temperature regime $\left({ }^{\circ} \mathbf{C}\right)^{x}$} & \multicolumn{2}{|c|}{ Triadimefon-sensitive isolate $^{w}$} & \multicolumn{2}{|c|}{ Triadimefon-resistant isolate } \\
\hline & Experiment 1 & Experiment 2 & Experiment 1 & Experiment 2 \\
\hline $22(24 h)^{y}$ & $43.0 \pm 4.04$ & $42.7 \pm 2.60$ & $54.3 \pm 2.18$ & $43.3 \pm 2.19$ \\
\hline $25(24 \mathrm{~h})$ & $47.7 \pm 5.24$ & $53.0 \pm 2.52$ & $64.0 \pm 1.52$ & $54.7 \pm 2.40$ \\
\hline $15(24 \mathrm{~h})$ & $26.0 \pm 2.08^{* z}$ & $32.3 \pm 4.91$ & $41.0 \pm 2.31^{*}$ & $34.7 \pm 4.83$ \\
\hline $32(6 h), 22(18 h)$ & $31.0 \pm 1.73^{*}$ & $40.0 \pm 6.66$ & $45.7 \pm 2.73$ & $43.0 \pm 1.00$ \\
\hline 32 (12 h), 22 (12 h) & $24.7 \pm 2.85^{*}$ & $36.0 \pm 4.04$ & $45.7 \pm 2.60$ & $38.7 \pm 0.88$ \\
\hline $32(24 \mathrm{~h})$ & $20.3 \pm 1.85^{*}$ & $42.3 \pm 2.03$ & $24.0 \pm 3.60 *$ & $41.7 \pm 6.69$ \\
\hline 36 (3 h), $22(21$ h) & $33.7 \pm 2.90$ & $34.0 \pm 3.79$ & $50.7 \pm 3.18$ & $37.0 \pm 3.05$ \\
\hline $36(6 h), 22(18 h)$ & $20.7 \pm 2.03 *$ & $13.3 \pm 3.48^{*}$ & $42.7 \pm 2.85$ & $7.0 \pm 0.58^{*}$ \\
\hline $40(1 \mathrm{~h}), 22(23 \mathrm{~h})$ & $29.0 \pm 2.51^{*}$ & $19.3 \pm 3.28^{*}$ & $46.7 \pm 5.89$ & $24.3 \pm 3.76^{*}$ \\
\hline 40 (3 h), 22 (19h) & $1.0 \pm 0.58^{*}$ & $0.7 \pm 0.33^{*}$ & $0.3 \pm 0.33^{*}$ & $0.0 \pm 0.00 *$ \\
\hline
\end{tabular}

${ }^{\mathrm{v}}$ The conidial germination percentage was determined by examining 100 conidia collected from the inoculated leaf disc surface after a $24 \mathrm{~h}$ exposure to the stated temperature regimes. The experiment was performed in three replications. Means are stated \pm one standard error of the mean.

${ }^{w}$ The triadimefon-sensitive isolate originated from a vineyard in Yuba County, California. The triadimefon-resistant isolate originated from a vineyard in Monterey County, California. Isolates were cultured twice from single conidia prior to the experiment.

${ }^{\mathrm{x}}$ Temperatures are stated in chronological order, followed by exposure times in hours in parentheses.

${ }^{\mathrm{y}}$ The germination percentage after exposure to $22^{\circ} \mathrm{C}$ for $24 \mathrm{~h}$ served as the control treatment to which germination at the other temperature regimes was compared by means of Dunnett's test.

$\mathrm{z} *=$ Germination percentage significantly different from germination percentage after exposure to $22^{\circ} \mathrm{C}$ for $24 \mathrm{~h}$. (Dunnett's test, $\alpha=0.05$ ). 
regimes was lower than germination at $22^{\circ} \mathrm{C}$, but the differences were not always significant or consistent among the experiments. Only after exposure to $40^{\circ} \mathrm{C}$ for $3 \mathrm{~h}$ was germination of both isolates zero or near zero in both experiments.

Effect of temperature and triadimefon on sporulation. The exploratory analysis of the entire data set indicated that the main effects of experiment, temperature and treatment, were highly significant $(P<0.01)$, but the main isolate effect was not significant $(P=$ 0.40). All two-way interactions involving temperature (experiment $\times$ temperature, isolate $\times$ temperature, temperature $\times$ treatment) and isolate $\times$ treatment were significant $(P<0.01)$. All three-way interactions with temperature (experiment $\times$ temperature $\times$ isolate, experiment $\times$ temperature $\times$ treatment, and temperature $\times$ isolate $\times$ treatment) were also significant $(P<0.01)$. The effect of the sampling time and interactions with the other variables were all highly significant $(P<0.01)$, except for the interaction with experiment, isolate and treatment $(P=$ 0.25 ). The significant interactions justified the further analysis of the data sets for each separate experiment, temperature regime, and isolate (Table 2). The $F$ values for the interaction between sampling time and triadimefon treatment reflected best the effect of the successive triadimefon treatments over time.

Favorable temperature regimes provided detectable $U$. necator sporulation for the entire experiment duration of 51 to 53 days. The numbers of conidia in the watertreated isolates slowly declined at these temperatures, but the final counts were higher than zero. This was the case at daily temperatures fluctuating between 15 and $25^{\circ} \mathrm{C}, 25^{\circ} \mathrm{C}$ for $24 \mathrm{~h}, 32^{\circ} \mathrm{C}$ for $6 \mathrm{~h}, 36^{\circ} \mathrm{C}$ for $3 \mathrm{~h}$, and $40^{\circ} \mathrm{C}$ for $1 \mathrm{~h}$ (Fig. $1 \mathrm{~B}$ to $\mathrm{D}, \mathrm{G}$, and $\mathrm{I}$ ). At $15^{\circ} \mathrm{C}$, the numbers of conidia from the water-treated isolates stayed at levels similar to the initial count throughout the experiment (Fig. 1A). The temperature regimes at which continuous sporulation was not supported were $32^{\circ} \mathrm{C}$ for $24 \mathrm{~h}, 36^{\circ} \mathrm{C}$ for $6 \mathrm{~h}$, and $40^{\circ} \mathrm{C}$ for $3 \mathrm{~h}$ (Fig. 1F, H, and J). At these temperature regimes, the numbers of conidia declined rapidly and were zero or near zero after 23 days, regardless of isolate or treatment. At $32^{\circ} \mathrm{C}$ for $11 \mathrm{~h}$, sporulation of both isolates also declined rapidly, but after 23 days it was zero or near zero only for the triadimefon-resistant isolate. The triadimefon-sensitive isolate continued to sporulate at low levels to the end of the experiment (Fig. 1E).

At the favorable temperature regimes, the $F$ values of the interaction between treatment and sampling time were consistently higher for the sensitive than for the resistant isolate (Table 2). For the sensitive isolates, these $F$ values were always significant, except for the second experiment at $32^{\circ} \mathrm{C}$ for $6 \mathrm{~h}$ and the first experiment at $36^{\circ} \mathrm{C}$ for $3 \mathrm{~h}$. In the latter two cases the $F$ values were close to significance with probabilities of 0.07 and 0.08 , respectively. When the sensitive isolate was treated with triadimefon, the numbers of conidia rapidly declined and were zero or near zero after 23 days (Fig. $1 \mathrm{~A}$ to $\mathrm{J})$. For the triadimefon- and watertreated resistant isolate, the difference in conidial counts was much smaller. $F$ values for the interactions between treatment and sampling time were significant only at $15^{\circ} \mathrm{C}$ for $24 \mathrm{~h}, 25^{\circ} \mathrm{C}$ for $24 \mathrm{~h}$, and $40^{\circ} \mathrm{C}$ for $1 \mathrm{~h}$, but they were lower than those for the sensitive isolate. $F$ values were not significant at temperatures fluctuating between 15 and $25^{\circ} \mathrm{C}, 32^{\circ} \mathrm{C}$ for $6 \mathrm{~h}$, and $36^{\circ} \mathrm{C}$ for $3 \mathrm{~h}$ (Table 2).

At the higher temperature regimes $\left(32^{\circ} \mathrm{C}\right.$ for $24 \mathrm{~h}, 32^{\circ} \mathrm{C}$ for $11 \mathrm{~h}, 36^{\circ} \mathrm{C}$ for $6 \mathrm{~h}$, and $40^{\circ} \mathrm{C}$ for $3 \mathrm{~h}$ ), the $F$ values for the interaction between treatment and sampling time were not significant for either isolate.

\section{DISCUSSION}

$U$. necator was able to infect and sporulate on grape foliage at a wide range of temperatures. Conidial germination after $24 \mathrm{~h}$ was highest at 22 and $25^{\circ} \mathrm{C}$, but

Table 2. $F$ values for the interaction between treatment ${ }^{\mathrm{v}}$ and sampling time ${ }^{\mathrm{w}}$ for a triadimefon-sensitive and a triadimefon-resistant $U n c i n u l a ~ n e c a t o r$ isolate ${ }^{\mathrm{x}}$, each subjected to one of 10 different temperature regimes

\begin{tabular}{|c|c|c|c|c|c|}
\hline \multirow[b]{2}{*}{ Daily temperature regime } & \multirow[b]{2}{*}{ Experiment } & \multicolumn{2}{|c|}{ Sensitive isolate } & \multicolumn{2}{|c|}{ Resistant isolate } \\
\hline & & $F$ value & $P>F$ & $F$ value & $P>F$ \\
\hline \multirow{2}{*}{$15^{\circ} \mathrm{C}(24 \mathrm{~h})$} & 1 & 80.87 & $0.0001 * * * \mathrm{z}$ & 3.65 & $0.02 * * *$ \\
\hline & 2 & 39.71 & $0.0001 * * *$ & 3.64 & $0.02 * * *$ \\
\hline \multirow[t]{2}{*}{$25^{\circ} \mathrm{C}(24 \mathrm{~h})$} & 1 & 5.67 & $0.002 * * *$ & 9.25 & $0.0001 * * *$ \\
\hline & 2 & 20.35 & $0.0001 * * *$ & 5.26 & $0.003 * * *$ \\
\hline \multirow[t]{2}{*}{$15^{\circ} \mathrm{C}(11 \mathrm{~h}), 25^{\circ} \mathrm{C}(11 \mathrm{~h})$} & 1 & 10.31 & $0.0001 * * *$ & 0.85 & 0.53 \\
\hline & 2 & 15.87 & $0.0001 * * *$ & 0.98 & 0.45 \\
\hline \multirow[t]{2}{*}{$32^{\circ} \mathrm{C}(24 \mathrm{~h})$} & 1 & 0.71 & 0.63 & 2.68 & 0.052 \\
\hline & 2 & 1.22 & 0.33 & 1.79 & 0.16 \\
\hline \multirow[t]{2}{*}{$32^{\circ} \mathrm{C}(6 \mathrm{~h}), 22^{\circ} \mathrm{C}(16 \mathrm{~h})$} & 1 & 7.15 & $0.0006 * * *$ & 1.19 & 0.35 \\
\hline & 2 & 2.44 & 0.07 & 1.22 & 0.34 \\
\hline \multirow{2}{*}{$32^{\circ} \mathrm{C}(11 \mathrm{~h}), 22^{\circ} \mathrm{C}(11 \mathrm{~h})$} & 1 & 1.05 & 0.42 & 0.90 & 0.50 \\
\hline & 2 & 2.16 & 0.10 & 2.45 & 0.07 \\
\hline \multirow[t]{2}{*}{$36^{\circ} \mathrm{C}(3 \mathrm{~h}), 22^{\circ} \mathrm{C}(19 \mathrm{~h})$} & 1 & 2.32 & 0.08 & 2.25 & 0.09 \\
\hline & 2 & 2.99 & $0.035^{* * * *}$ & 0.70 & 0.63 \\
\hline \multirow[t]{2}{*}{$36^{\circ} \mathrm{C}(6 \mathrm{~h}), 22^{\circ} \mathrm{C}(16 \mathrm{~h})$} & 1 & 1.55 & 0.22 & 1.94 & 0.13 \\
\hline & 2 & 2.08 & 0.12 & 0.66 & 0.66 \\
\hline \multirow[t]{2}{*}{$40^{\circ} \mathrm{C}(1 \mathrm{~h}), 22^{\circ} \mathrm{C}(21 \mathrm{~h})$} & 1 & 7.36 & $0.0005^{* * *}$ & 4.55 & $0.006 * * *$ \\
\hline & 2 & 11.19 & $0.0001 * * *$ & 2.78 & $0.046^{* * *}$ \\
\hline \multirow[t]{2}{*}{$40^{\circ} \mathrm{C}(3 \mathrm{~h}), 22^{\circ} \mathrm{C}(19 \mathrm{~h})$} & 1 & 0.59 & 0.71 & 1.32 & 0.29 \\
\hline & 2 & 0.32 & 0.90 & 0.93 & 0.48 \\
\hline
\end{tabular}

${ }^{v}$ Triadimefon (Bayleton 50\% DF) was applied to the U. necator-infected plants at the beginning of the experiment, 19 to 23 days, and 41 to 43 days after the beginning of the experiment, at $150 \mathrm{mg} /$ liter in distilled water. Infected controls were sprayed with distilled water.

${ }^{\text {w}}$ Conidia were counted in a sample collected from the $U$. necator-infected plants at six times during the experiment. The first sampling was performed when $U$. necator was exposed to the stated temperature regimes. The second, third, fourth, fifth, and sixth samplings were performed after 9 to 12,19 to 23,30 to 34,41 to 43 , and 51 to 53 days, respectively.

${ }^{\mathrm{x}}$ The triadimefon-sensitive $U$. necator isolate originated from a vineyard in Yuba County, California. This vineyard was isolated from other vineyards and had never been exposed to demethylation-inhibiting (DMI) fungicides. The resistant isolate originated from a vineyard in Monterey County, California that was exposed to frequent DMI fungicide applications. Isolates were cultured twice from single conidia. The $\mathrm{EC}_{50}$ of triadimefon was $2.5 \pm 0.55$ $\mathrm{mg} / \mathrm{liter}$ for the sensitive isolate, and $48.7 \pm 3.77 \mathrm{mg} / \mathrm{liter}$ for the resistant isolate. The sensitive isolate was completely inhibited by $30 \mathrm{mg} / \mathrm{liter}$ triadimefon and the resistant isolate by $200 \mathrm{mg} / \mathrm{liter}$ triadimefon.

y Daily temperatures for each temperature regime are stated in chronological order, followed by exposure times in $\mathrm{h}$ in parentheses.

${ }^{\mathrm{z}}$ Significant at $\alpha=0.05$ at 5 and 20 degrees of freedom. 


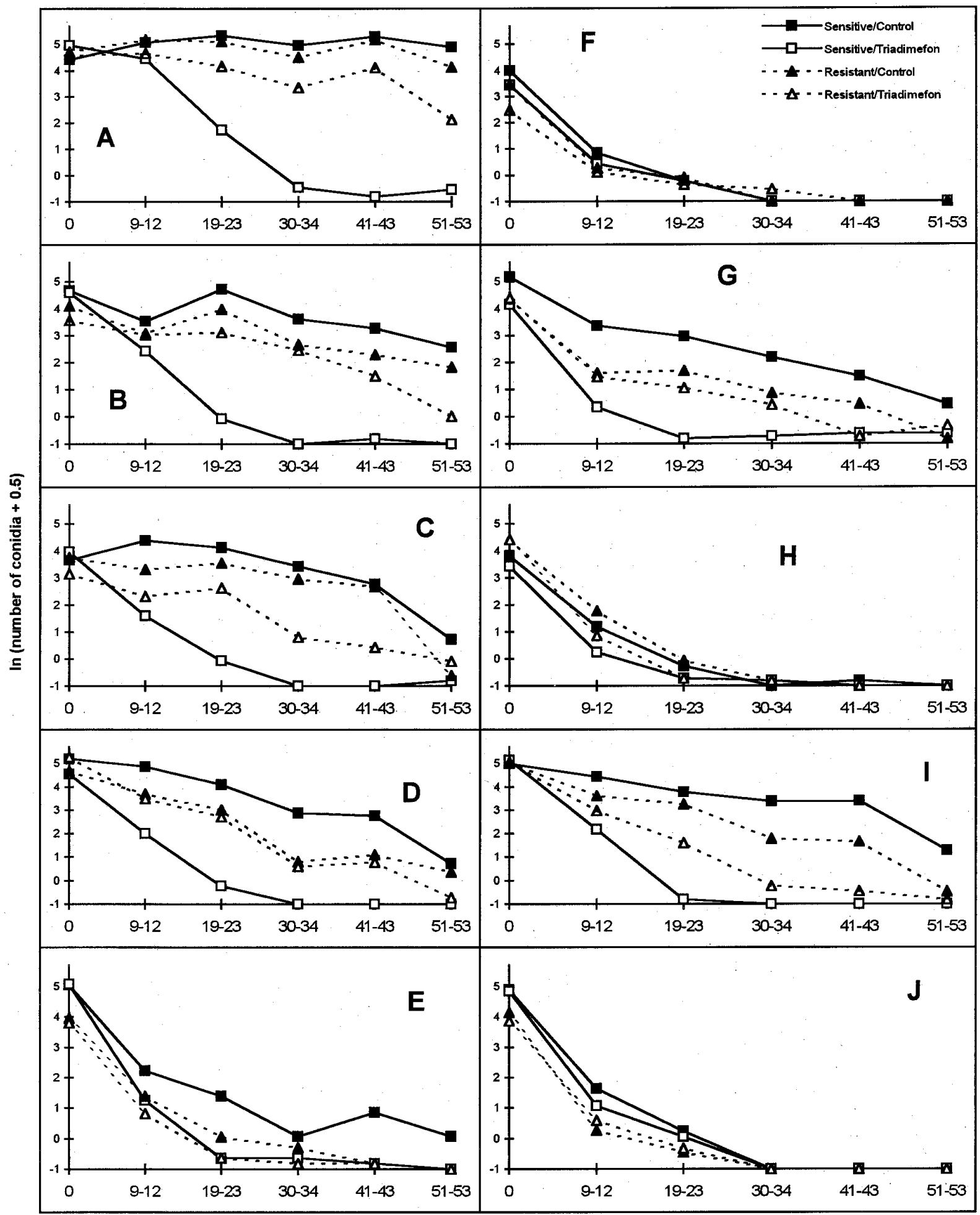

Days

Fig. 1. Conidial counts of samples from two container-held Uncinula necator isolates, sensitive and resistant to triadimefon. Conidia were counted in samples taken from the $U$. necator-infected plants at six times during the experiment. The triadimefon-sensitive $U$. necator isolate originated from a vineyard which had never been exposed to DMI-fungicides. The resistant isolate originated from a Central Coast vineyard in which powdery mildew control by triadimefon had been unsatisfactory. Isolates were cultured twice from single conidia. The $\mathrm{EC}_{50}$ of triadimefon was $2.5 \pm 0.55 \mathrm{mg} /$ liter for the sensitive isolate, and $48.7 \pm 3.77$ $\mathrm{mg} / \mathrm{liter}$ for the resistant isolate. The sensitive isolate was completely inhibited by $30 \mathrm{mg} /$ liter triadimefon, and the resistant isolate by $200 \mathrm{mg} / \mathrm{liter}$ triadimefon. The samples were subjected to three triadimefon applications over a 53-day period at daily temperature regimes of (A) $15^{\circ} \mathrm{C}$, (B) $15^{\circ} \mathrm{C}$ for $11 \mathrm{~h}$ and $25^{\circ} \mathrm{C}$ for 11 $\mathrm{h},(\mathbf{C}) 25^{\circ} \mathrm{C}$, (D) $32^{\circ} \mathrm{C}$ for $6 \mathrm{~h}$ and $22^{\circ} \mathrm{C}$ for $16 \mathrm{~h},(\mathbf{E}) 32^{\circ} \mathrm{C}$ for $11 \mathrm{~h}$ and $22^{\circ} \mathrm{C}$ for $11 \mathrm{~h},(\mathbf{F}) 32^{\circ} \mathrm{C},(\mathbf{G}) 36^{\circ} \mathrm{C}$ for $3 \mathrm{~h}$ and $22^{\circ} \mathrm{C}$ for $19 \mathrm{~h},(\mathbf{H}) 36^{\circ} \mathrm{C}$ for $6 \mathrm{~h} \mathrm{and} 16^{\circ} \mathrm{C}$ for $16 \mathrm{~h}$, (I) $40^{\circ} \mathrm{C}$ for $1 \mathrm{~h}$ and $22^{\circ} \mathrm{C}$ for $21 \mathrm{~h}$, and $(\mathbf{J}) 40^{\circ} \mathrm{C}$ for $3 \mathrm{~h}$ and $22^{\circ} \mathrm{C}$ for $19 \mathrm{~h}$. The duration of temperature change was $1 \mathrm{~h}$. The first sampling was performed when $U$. necator was exposed to the stated temperature regimes. The second, third, fourth, fifth and sixth samplings were performed after 9 to 12,19 to 23,30 to 34,41 to 43 , and 51 to 53 days, respectively. The data points represent the average of conidial counts of two experiments, each performed in three replications. Prior to transformation of conidial counts to natural logarithms, a value of 0.5 was added. The y-axis-values of $-1,1,2,3,4$, and 5 represent 0 , and approximately 220, 690, 1960, 5400, and 14800 conidia/ $\mathrm{cm}^{2}$ leaf surface area. Triadimefon (Bayleton 50\% DF) was applied at $150 \mathrm{mg} / \mathrm{liter}$ in distilled water to the U. necator-infected plants after the first, third, and fifth collection of samples for conidial counts. Infected control plants were sprayed with distilled water. 
nearly inhibited after exposure to $40^{\circ} \mathrm{C}$ for $3 \mathrm{~h}$. Inhibition of germination alone, therefore, could have accounted for the rapid decline in conidial counts following a daily exposure to $40^{\circ} \mathrm{C}$ for $3 \mathrm{~h}$. However, counts of both isolates also declined rapidly at incubations at $32^{\circ} \mathrm{C}$ for 11 and 24 $\mathrm{h}$, and $36^{\circ} \mathrm{C}$ for $6 \mathrm{~h}$. The latter temperatures did not inhibit germination to the same extent as exposure to $40^{\circ} \mathrm{C}$ for $3 \mathrm{~h}$. Delp (2) reported that germination occurred at temperatures as high as $33.5^{\circ} \mathrm{C}$, whereas infection was inhibited at temperatures higher than $31.5^{\circ} \mathrm{C}$. Most likely, impaired infection resulted in the decline in conidial numbers at daily exposures to $36^{\circ} \mathrm{C}$ for $6 \mathrm{~h}$ and $32^{\circ} \mathrm{C}$ for 11 and $24 \mathrm{~h}$. The decline in conidial counts was more gradual at all the other temperature regimes. This may have been due to the fact that processes of germination, infection, and subsequent sporulation were sufficient for prolonged detectable sporulation of U. necator.

Because of the high RH in the containers, the difference between leaf and air temperature most likely was very small. The temperatures used in the study were probably representative of leaf surface temperatures. Although these studies were performed in growth chambers, the temperature regimes might prove useful for disease risk assessment and timing of fungicide applications in the vineyard. A disease risk assessment model for powdery mildew currently used in California operates mainly on temperature. The model increases an index value for disease pressure when temperatures are between 21 and $30^{\circ} \mathrm{C}$ for at least $6 \mathrm{~h}$ per day $(5,8)$. The index value is reduced when these conditions are not met. In our studies, an established $U$. necator population was able to survive exposure to temperatures of $15^{\circ} \mathrm{C}$ for up to 53 days without obvious reductions in the numbers of conidia. Therefore, the assumption can be made that $U$. necator colonies that were established prior to a prolonged period with temperatures of $15^{\circ} \mathrm{C}$ resume their rapid development and reproduction immediately when temperatures rise from 15 to between 21 and $30^{\circ} \mathrm{C}$. Therefore, disease risk may not diminish for an extended period of time after temperatures have fallen below $21{ }^{\circ} \mathrm{C}$. Under such conditions, fungicide applications at regular intervals may be feasible on established infections. When daily leaf temperatures within the canopy attain 32,36 , or $40^{\circ} \mathrm{C}$ for more than 11,6 , and $3 \mathrm{~h}$, respectively, fungicide application intervals may perhaps be lengthened without loss of control. Summer air temperatures of 36 and $40^{\circ} \mathrm{C}$ are consistently reached in the Sacramento and San Joaquin Valleys. Incorporation of the duration of daily maximum temperatures may be a valuable addition to disease risk assessment models used in central California.
At daily temperature regimes that supported prolonged infection and conidial production, the isolates reacted differently to the triadimefon treatments. At all temperature regimes, the numbers of conidia in the triadimefon-treated sensitive isolate declined rapidly and were zero or near zero after 23 days. With a minimal inhibitory triadimefon concentration of $30 \mathrm{mg} / \mathrm{liter}$, growth of the sensitive isolate in the containers may have been inhibited completely after the first triadimefon application. At all temperature regimes favorable for sporulation, the resistant isolate continued to sporulate at detectable levels, even after the second and third triadimefon application. With a minimal inhibitory triadimefon concentration of $200 \mathrm{mg} / \mathrm{liter}$, the resistant isolate was able to survive the successive triadimefon applications.

Triadimefon resistance in the resistant isolate appeared to be more evident at 15 than at $25^{\circ} \mathrm{C}$. Temperature has an effect on the volatility of triadimefon, which may influence the amount of triadimefon absorbed by the plant tissue (K. H. Kuck, personal communication). In addition, it was demonstrated that the conversion rate from triadimefon to its active component triadimenol in wheat plants was highly temperature dependent (6). This conversion rate decreased at lower temperatures (6). The conversion to triadimenol also occurs in grape and is also most likely temperature dependent (K. H. Kuck, personal communication).

Although the differential manifestation of triadimefon resistance can be explained by the effect of temperature on development of $U$. necator alone, the effect of temperature on triadimefon uptake and its conversion to triadimenol may also be of influence. It is quite possible that volatility of triadimefon was lowest at $15^{\circ} \mathrm{C}$. Therefore, this temperature may have resulted in the highest uptake of triadimefon in the plant, but also may have resulted in a slow conversion of triadimefon to triadimenol. The resulting low triadimenol concentration in the plant may have effectively inhibited further growth of the sensitive isolate, but the concentration may have been too low to affect development of the resistant isolate. This probably was also the case at temperatures fluctuating between 15 and $25^{\circ} \mathrm{C}$.

At $25^{\circ} \mathrm{C}$ for $24 \mathrm{~h}$ and at $40^{\circ} \mathrm{C}$ for $1 \mathrm{~h}$, the resistant isolate demonstrated a significant treatment effect, but in general it was still less pronounced than the treatment effect on the sensitive isolate. At these temperature regimes, the possible higher conversion rate may have resulted in a higher triadimenol concentration in the grape leaf tissue, resulting in a stronger growth reduction of the resistant isolate than at $15^{\circ} \mathrm{C}$ or at temperatures fluctuating between 15 and $25^{\circ} \mathrm{C}$. At $32^{\circ} \mathrm{C}$ for $6 \mathrm{~h}$ and $36^{\circ} \mathrm{C}$ for 3 $\mathrm{h}$, the rate of decline in conidial counts was higher in both isolates. This was the main reason why treatment effects were less pronounced than at the previously mentioned temperatures. The decline in numbers of conidia was even more rapid at $32^{\circ} \mathrm{C}$ for $24 \mathrm{~h}, 32^{\circ} \mathrm{C}$ for $11 \mathrm{~h}, 36^{\circ} \mathrm{C}$ for $6 \mathrm{~h}$, and $40^{\circ} \mathrm{C}$ for $3 \mathrm{~h}$, thus masking any treatment effect. A presumed increased evaporation of triadimefon may have reduced absorption by the plant tissue, subsequently resulting in a less pronounced treatment effect. However, the effect of a lesser absorption of triadimefon was probably minor in comparison to the adverse effect of high temperatures on $U$. necator.

Triadimefon has been used to control $U$. necator since 1982, and instances of unsatisfactory control have predominated in the cooler coastal regions of California or in other production areas with mild summer temperatures (4). There are several possible explanations for these observations. The average and maximum temperatures in the coastal areas of California generally are close to the optimum temperature range for asexual reproduction of $U$. necator. The higher asexual reproduction rate at moderate temperatures probably results in rapidly growing populations of both sensitive and resistant individuals. When DMI fungicides are applied, selection operates on a rapidly increasing subpopulation of resistant individuals. All DMI fungicides have remained more effective in the warmer Central and San Joaquin Valleys. High summer temperatures in these areas slow the asexual reproduction rate and generally prevent large population increases. Unsatisfactory control due to DMI fungicide resistance is most likely to be noticed when disease pressure is high, which is in part a function of temperature.

\section{ACKNOWLEDGMENTS}

We thank S. J. Vasquez for excellent technical assistance.

\section{LITERATURE CITED}

1. Chellemi, D. O., and Marois, J. J. 1991. Sporulation of Uncinula necator on grape leaves as influenced by temperature and cultivar. Phytopathology 81:197-201.

2. Delp, C. J. 1954. Effect of temperature and humidity on the grape powdery mildew fungus. Phytopathology 44:615-626.

3. Gadoury, D. M., and Pearson, R. C. 1991. Heterothallism and pathogenic specialization in Uncinula necator. Phytopathology 81:12871293.

4. Gubler, W. D., Ypema, H. L., Ouimette, D. G., and Bettiga, L. J. 1996. Occurrence and development of resistance in Uncinula necator to triadimefon, myclobutanil and fenarimol in California grapevines. Plant Dis. 80:902-909.

5. Gubler, W. D., Thomas, C. S., Weber, E., Luvisi, D., Leavitt, G., and Smith, R. 1997. Use of a weather station based disease risk assessment for control of grapevine powdery mildew in California. (Abstr.) Phytopathology 87:S36.

6. Kuck, K. H. 1987. Studies on the uptake of Bayleton in wheat leaves. Pflanzenschutz Nachr. Bayer 40:1-28. 
7. Ogawa, J. M., Gubler, W. D., and Manji, B. T. 1988. Effect of sterol biosynthesis inhibitors on diseases of stone fruits and grapes in California. Pages 262-287 in: Sterol Biosynthesis Inhibitors-Pharmaceutical and Agrochemical
Aspects. D. Berg and M. Plempel, eds. Ellis Horwood Ltd., Chichester, UK.

8. Thomas, C. S., Gubler, W. D., and Leavitt, G. 1994. Field testing of a powdery mildew disease forecast model on grapes in California.
(Abstr.) Phytopathology 84:1070.

9. Ypema, H. L., and Gubler, W. D. 1997. Sensitivity of Uncinula necator to benomyl, triadimefon, myclobutanil and fenarimol in California. Plant Dis. 81:293-297. 